\title{
Personalistyczna koncepcja administracji publicznej a bezdomność
}

\author{
Sławomir Fundowicz* \\ Streszczenie: Niniejszy artykuł porusza problematykę personalistycznej koncepcji administracji publicznej \\ w kontekście bezdomności. Omówiono koncepcję administracji publicznej, jak i filozoficzne pod- \\ stawy personalizmu, by następnie przejść do pojęcia zadania publicznego. Koniecznym stało się \\ przeanalizowanie kwestii godności osoby ludzkiej, jak i systemu pomocy bezdomnym. \\ Mając na uwadze personalistyczną koncepcję prawa administracyjnego podkreślono konieczność \\ patrzenia na bezdomność przez pryzmat osoby bezdomnej.
}

Słowa kluczowe: personalistyczna koncepcja administracji publicznej, filozoficzne podstawy personalizmu, godność osoby ludzkiej, system pomocy bezdomnym.

\section{Koncepcje administracji publicznej}

Koncepcja administracji publicznej zależy od poglądów tych, którzy je tworzą. Z koncepcji zaś wynika sposób rozwiązywania szczegółowych problemów. Sama koncepcja administracji publicznej uwarunkowana jest założeniami filozoficznymi, często nawet nieuświadomionymi. Najczęściej chodzi tutaj o założenia aksjologiczne, które jednak wynikają z antropologii lub ontologii. Na kształt współcześnie rozwijanych koncepcji administracji publicznej mogą więc mieć wpływ różne poglądy. Nie jest łatwo dokonać pełnej klasyfikacji poglądów mających wpływ na koncepcje administracji publicznej. Często są to bowiem koncepcje sięgające do wielu źródeł. Można jednak próbować wyodrębnić pewne wiodące kierunki. Są wśród nich:

- koncepcje humanistyczne,

- koncepcje normatywistyczne,

- koncepcje pragmatyczne,

- koncepcje socjalistyczne,

- koncepcje personalistyczne,

- koncepcje modernistyczne (ponowoczesne).
Po Il wojnie światowej przez chwilę wydawało się, że na czoło wyjdzie koncepcja personalistyczna. Za podstawę współczesnej teorii prawa i ładu społecznego uznać można Powszechną Deklarację Praw Człowieka przyjętą 10 grudnia 1948 r. przez Zgromadzenie Ogólne Narodów Zjednoczonych. Od ogłoszenia właśnie tego dokumentu w centrum zainteresowania prawnika stanął człowiek. Powszechna Deklaracja Praw Człowieka jest zbiorem praw pojętych nie jako lex - jako jakaś norma prawna, lecz jako ius - uprawnienie, które człowiek zawsze posiada i od nikogo uprawnień tych nie nabywa. Z natury rzeczy prawo jako uprawnienie stoi przed prawem rozumianym jako norma prawna, która ma kierować ludzkimi czynami w jakiejś społeczności. Zanim bowiem pojawi się jakakolwiek norma postępowania, już zastajemy w świecie realnie istniejących ludzi prawo,

\footnotetext{
* Sławomir Fundowicz

Katedra Prawa Administracyjnego

Wydział Prawa, Prawa Kanonicznego

i Administracji

Katolicki Uniwersytet Lubelski Jana Pawła II

Al. Racławickie 14, 20-950 Lublin

e-mail: makowiec@kul.lublin.pl
} 
które z człowiekiem jest nieodzownie związane [Krąpiec, 1996, s. 131].

Sama koncepcja praw człowieka określona w deklaracji z 1948 r. ma swoje źródło w personalistycznych koncepcjach J. Maritaina i E. Mouniera. Rozróżnili oni pojęcie indywiduum oraz pojęcie osoby. Zauważyli, że jednostkowość człowieka jest funkcją materii i dlatego nie wyodrębnia go w stosunku do grupy społecznej, ale podporządkowuje tej grupie na wzór podporządkowania komórki biologicznej całemu organizmowi. Natomiast człowiek jako osoba góruje nad społecznością i ta powinna być jemu przyporządkowana [Krąpiec, 1991, s. 320]. Również w materialnym prawie administracyjnym, w dziedzinie postępowania administracyjnego należy dążyć do realizacji tej formuły, według której człowiek jako jednostka jest państwu powinien, natomiast jako osoba jest wolny od państwa. Nie jest to reguła łatwa do rozpisania na czynniki pierwsze w perspektywie konkretnych sytuacji prawnych i stanów faktycznych, zwłaszcza gdy weźmie się pod uwagę ciągle trwające przeobrażenie rzeczywistości społeczno-gospodarczej, za którym stosunkowo wolno idą zmiany świadomości społecznej, także wśród tych, którzy tworzą i wykonują normy prawne [Zdyb, 1998, s. 115-116].

\section{Filozoficzne podstawy personalizmu}

Myśl personalistyczna została zapoczątkowana w drugiej połowie XIX w. Głównym jej ośrodkiem był wtedy uniwersytet w Bostonie [por. Gacka, 1996]. Był to wówczas personalizm indywidualistyczny, oparty na podstawach teologii protestanckiej [Głombik, 2002, s. 246].

Poglądy personalistyczne pojawiały się w różnych środowiskach narodowych; stąd można wyróżnić personalizm francuski, personalizm niemiecki, a także personalizm polski ${ }^{1}$. Łączyły się one także z różnymi kierunkami filozoficznymi, stąd wyróżnia się personalizm filozoficzno-religijny (Pierre Teilhard de Chardin, Nikołaj Bierdiajew), personalizm fenomenologiczny (Max Scheler, Edith Stein), personalizm egzystencjalny (Karl Jaspers, Gabriel Marcel), a także personalizm neotomistyczny (Jacques Maritain) [por. Bartnik, 1995]. Bez wątpienia w odniesieniu do porządku społeczno-prawnego największe znaczenie mają tutaj poglądy Emmanuela Mouniera i Jacquesa Maritaina.

Emmanuel Mounier (1905-1950), mimo bogatej twórczości, nie zostawił systematycznego opracowania dotyczącego własnych poglądów. Podkreśla on, że osoba nie jest bytem, nie jest też przedmiotem. Jest ona w człowieku tym, co nie może być traktowane jako przedmiot. Osoba to jedyna rzeczywistość, którą poznajemy, a zarazem tworzymy "od wewnątrz". Nigdy nie jest dana, a zawsze obecna. Osoba ludzka nie redukuje się ani do zespołu cech dających się nazwać i określić, ani też do pewnej szczególnej kombinacji ról społecznych [Płużański, 2002, s. 268]. Można posłużyć się tutaj metodą obrazowego opisu zastosowaną przez samego E. Mouniera: „Oto mój sąsiad. Jest on urzędnikiem (...). Jest on poza tym (...) jednym z Francuzów, jednym z mieszczan lub jednym z maniaków, jednym z socjalistów, jednym z katolików itd. Nie jest on jednak jednym z Bernardów Chartier. On jest Bernardem Chartier. Tysiąc sposobów, którymi mógłby go określić jako jeden z egzemplarzy pewnej klasy, dopomaga mi w zrozumieniu go, a zwłaszcza w posługiwaniu się nim (...) Są to jednak tylko poszczególne wycinki, ukazujące za każdym razem jeden aspekt jego istnienia. Sto tysięcy zdjęć fotograficznych nie tworzy jeszcze człowieka, który chodzi, myśli i chce" [Mounier, 1964, s. 8-9]. Tak rozumiane życie osobowe powoduje osamotnienie człowieka. Niepowtarzal-

Ten ostatni najpełniej zrealizowany przez W. Granata [por. Granat, 1961; Granat, 1976], a także K. Wojtyłę [por. Wojtyła, 1994]. 
ność bytu osobowego powoduje niemożliwość komunikacji treści życia osobowego. E. Mounier jednak dąży do przełamania owej izolacji, twierdząc że życie osobowe możliwe jest tylko we wspólnocie. Stąd parafrazuje myśl kartezjańską, głosząc Amo ergo sum, a więc to miłość jest dowodem istnienia osobowego, co najmniej tak przekonującym jak myślenie, i miłość też zapewni rozwiązanie dylematu izolacji i komunikacji międzyosobowej [Płużański, 2002, s. 269-270]. Wśród relacji międzyludzkich E. Mounier odróżnia relacje rzeczowe i osobowe. Te drugie są nacechowane miłością, dostrzeganiem i uznaniem w drugim człowieku osoby, działaniem na korzyść jej rozwoju, niezastępowalnej. Pierwsze zaś, dominujące w realnym świecie, wyznaczają drogę do depersonalizacji, gdyż sprowadzają jednostkę do jej funkcji społecznej, w której może być łatwo zastąpiona. Ponadto zauważa E. Mounier konieczność wprowadzenia równowagi między życiem „wewnętrznym” i „zewnętrznym”. Załamanie tej równowagi grozi popadnięciem albo w nadmierną interioryzację, którą to sytuację E. Mounier nazywa „alienacją Narcyza”, gdyż dominuje tutaj egocentryzm jednostki, albo w całkowite urzeczowienie, nazwane "alienacją Herkulesa", kiedy jednostka wypełnia swe życie posiadaniem rzeczy. W obydwu przypadkach mamy do czynienia z deformacją życia osobowego. Tylko więc równowaga daje szansę urzeczywistnienia pełni bytu osobowego [ibidem, s. 271-272].

Jacques Maritain (1882-1973) najpełniej przedstawił swoją koncepcję personalistyczną w pracy z 1936 r. Humanizm integralny ${ }^{2}$. Ujawnia się w niej jako tomista, ale rozumie ów tomizm w swój własny sposób: "(...) według mnie odpowiada on faktowi, że tomizm nie tylko ma za zadanie kształcić i spełniać rolę dydaktyczną, lecz ma także podjąć się rozwiązania konkretnych proble-

Praca ta ukazała się w języku polskim dopiero w 1960 r. [Maritain, 1960, 1981]. mów, które życie przynosi; a ponieważ te problemy nowego <chrześcijaństwa> mają dla nas wielkie znaczenie, chciałbym je dziś krótko scharakteryzować w świetle zasad św. Tomasza z Akwinu" [Maritain, 1935, s. 2]. J.Maritain dążył do tego, by personalizm przenikał życie społeczne, by określał prawdziwie chrześcijańską myśl oraz praktykę polityczną, a także by techniczna racjonalizacja sposobów życia publicznego stale miała na uwadze humanizm osoby oraz demokratyczną naturę nowego, zhumanizowanego społeczeństwa przyszłości [Głombik, 2002, s. 247]. Personalizm J. Maritaina opierał się na tezie, że natura ludzka jest bytem złożonym, składającym się z tego, co jest w nim jednostkowe, indywidualne, oraz tego, co stanowi o jego duchowym, osobowym wymiarze. Człowiek poprzez swoją fizyczną strukturę, dany mu element cielesności wraz z wszystkimi wynikającymi stąd społecznymi powinnościami, uwikłaniami i następstwami, jest jednostką i przejawem przyrodniczego gatunku, do którego przynależy, wchodząc wraz z nim w skład wielkiego materialnego porządku świata i rządzących nim praw. Ale człowiek to nie tylko jednostka fizyczna, ale także osoba. W tym wymiarze charakteryzuje go życie duchowe, właściwe są mu wewnętrzne akty wyborów, dążeń, intelektualnych samookreśleń, pozwalające mu wykroczyć poza świat przyrody i kultury, a ukazujące jego niepowtarzalny status osoby jako ostoi moralności i godności [ibidem, s. 247-248]. J. Maritain podkreślał: „Człowiek jest w całości jednostką i również w całości osobą" [Maritain, 1998, s. 327]. Są to dwa aspekty jednego i tego samego bytu ludzkiego, z tym że osobie przysługuje nadrzędność i prymat bezwzględny, a świat jednostki, natury i kultury pełni rolę instrumentalną wobec trwania osoby [Głombik, 2002, s. 248-249]. J. Maritain wprowadza pojęcie "konkretnego ideału historycznego". Jest to przeciwieństwo utopii, idealna esencja możliwa do zrealizowania w danych konkretnych warunkach. Przedstawia tylko „linie 
sił i zarysy rzeczywistości przyszłej, które powinny być w następstwie określone" [Maritain, 1981, s. 96].

\section{Pojęcie zadania publicznego}

J. Boć definiuje administrację publiczną jako przejęte przez państwo i realizowane przez jego zawisłe organy, a także organy samorządu terytorialnego zaspokajanie zbiorowych i indywidualnych potrzeb obywateli wynikających ze współżycia ludzi w społecznościach [Boć, 2004, s. 16]. Obok wielu innych elementów tej definicji na uwagę zasługuje związanie trzech pojęć: państwo (lub samorząd terytorialny)-obywatel-społeczność. Państwo zaspokaja potrzeby obywatela (choć pełniej należałoby powiedzieć człowieka, który przecież nie musi być obywatelem), dlatego że żyje on w społeczności [Fundowicz, 2003, s. 106-107]. Swoją definicję tak komentuje sam Autor: „Wydaje się, że proponowanemu tu określeniu można przypisać istotne funkcje. Przede wszystkim przywraca ono właściwy wymiar państwowej i samorządowej dbałości o dobro obywateli, wskazując zarazem na służebną rolę administracji. Przyjęcie takiego sposobu patrzenia na administrację sugeruje możliwość zwiększenia podmiotowego traktowania obywateli w konstruowaniu prawa materialnego, w tym także prawa konstytucyjnego, które powinno eksponować zadbanie o interesy obywateli w pierwszym rzędzie. Określenie to może być też potraktowane jako punkt wyjścia w budowaniu kryteriów podziału prawa administracyjnego. Odpowiada ono nadto wymogom ukazywania rozbieżności między praktyką administrowania a teoretycznymi wymogami jej treści postulowanej. Inaczej mówiąc - takie ujęcie administracji ma określone znaczenie społeczne, wyrażające się w ocenie przedsięwzięć administracyjnych pod względem ich zgodności ze zbiorowymi i indywidualnymi potrzebami obywateli. Daje wreszcie możliwość oceny efektywno- ści działania administracji; w każdym czasie widać bowiem wyraźnie, czy administracja zaspokaja te potrzeby" [Boć, 2004, s. 17].

Tak więc za zadanie publiczne można uznać przejęte przez państwo zaspokajanie zbiorowych i indywidualnych potrzeb człowieka, wynikających ze współżycia ludzi w społecznościach. W tak definiowanym zadaniu publicznym można wyróżnić dwa elementy: materialny i formalny. Pierwszy wypełnia się w stwierdzeniu, że chodzi o zaspokajanie zbiorowych i indywidualnych potrzeb człowieka, wynikających ze współżycia ludzi w społeczności. W związku z coraz pełniejszym poznaniem człowieka i jego społecznej natury zmienia się też i zakres obejmowany pojęciem zadania publicznego. Za aspektem materialnym podąża aspekt formalny, polegający na tym, że państwo przejmuje zaspokajanie wcześniej ustalonych potrzeb. Przejęcie przez państwo dokonuje się przez ustalenie $\mathrm{w}$ normie prawnej pewnych działań jako zadań publicznych albo przez powszechne przypisywanie pewnych działań do zakresu zadań publicznych w ramach obrotu prawnego, albo też na podstawie bezspornego, niebudzącego wątpliwości domniemania, że określone działanie jest wykonywaniem zadania publicznego, którego podstawą jest fakt, że działanie to podejmuje osoba prawna prawa publicznego, a działanie to nie zostało dookreślone w normie prawnej jako czynność prawna prawa prywatnego.

Zawsze jednak chodzi o zaspokajanie potrzeb człowieka. Najszybciej odkryto znaczenie potrzeb człowieka dla jego funkcjonowania w społeczności na gruncie nauki o organizacji i zarządzaniu. Za istotny punkt zwrotny w rozwoju tej nauki przyjmuje się eksperymenty przeprowadzone w Hawthorne (przedmieście Chicago) od połowy lat dwudziestych do początków lat czterdziestych XX w. W 1924 r. kierownictwo General Electric Company zainicjowało cykl eksperymentów, które były początkowo zapro- 
jektowane i prowadzone przez inżynierów w zakładach Hawthrone Works. Eksperymenty początkowo polegały na badaniu wpływu rozmaitych poziomów natężenia oświetlenia na wydajność pracy robotników. Stworzono dwie grupy robotników wykonujących podobną pracę: eksperymentalną, która pracowała przy zmieniającym się natężeniu światła oraz kontrolną, która pracowała przy stałym poziomie natężenia. Okazało się, że mimo różnicy natężenia światła w obu grupach wydajność pracy wzrastała. Wezwano do udziału w eksperymencie wówczas Eltona Mayo, profesora Uniwersytetu Harvarda. Badania prowadzone przez Mayo w latach 1927-1932 doprowadziły do podobnych obserwacji. Wydajność wyselekcjonowanej grupy systematycznie wzrastała niezależnie od zmian w warunkach zewnętrznych. Przyjęło się nazywać te wyniki efektem Hawthorne, który polega na tym, że sam sposób organizowania i przeprowadzania badań implikuje określone reakcje u osób będących ich przedmiotem; reakcje te traktowane są jako informacje na temat rzeczywistości społecznej. Mayo postawił wówczas tezę, że zadowolenie z pracy prowadzi do wzrostu wydajności [zob. Chrisidu-Budnik et al., 2005, s. 62-64].

Wkrótce rozwinęły się badania psychodynamiczne, akcentujące rolę wewnętrznych wyznaczników w zachowaniach człowieka, szczególnie potrzeb i emocji. Do najbardziej znanych koncepcji psychodynamicznych należy hierarchia potrzeb opracowana przez amerykańskiego psychologa Abrahama Maslowa. W hierarchii tej zostały umieszczone:

a) potrzeby fizjologiczne - głód pragnienie, seks itd.;

b) potrzeby bezpieczeństwa - pewności, stałości, zależności, opieki, wolności od strachu, od lęku i chaosu, potrzeba struktury, porządku, prawa, ograniczeń, silnego opiekuna itd.; c) potrzeby afiliacji - kontaktów społecznych, miłości, czułości, przynależności;

d) potrzeby szacunku - osiągnięć i prestiżu;

e) potrzeby samorealizacji - pragnienie samo urzeczywistnienia, to znaczy zrealizowania swoich pragnień, zdolności oraz zainteresowań; potrzeby poznawcze, a więc rozumienia otaczającej nas rzeczywistości, oraz potrzeby estetyczne, czyli odczuwania piękna [Koźmiński, Piotrowski, 1997, s. 402].

\section{Godność osoby ludzkiej}

Trzeba odnaleźć cechy charakterystyczne człowieka jako bytu osobowego. W klasycznej filozofii wymienia się tutaj: poznanie intelektualne, miłość, wolność, podmiotowość wobec prawa, zupełność oraz godność [Krąpiec, 1993, s. 133-142]. W Konstytucji Rzeczypospolitej Polskiej z dnia 2 kwietnia 1997 r. $^{3}$ w sposób szczególny zwrócona jest uwaga na dwie z tych cech: godność i wolność.

Przy stosowaniu Konstytucji należy dbać o zachowanie przyrodzonej godności człowieka ${ }^{4}$. Przyrodzona i niezbywalna godność człowieka stanowi źródło wolności i praw człowieka i obywatela. Władze publiczne są zobowiązane do poszanowania i ochrony godności człowieka, gdyż jest ona nienaruszalna (art. 30 Konstytucji RP). Godność człowieka przejawia się w tym, że człowiek będąc celem wszelkiego postępowania, nie tłumaczy się ostatecznie przez zespół relacji rzeczowych, poprzez przyrodę, ale poprzez odniesienie do innej, drugiej osoby. Świadomego działania człowieka nie da się wytłumaczyć przez odwołanie się do jakiegoś kompleksu czy zestawu rzeczowych relacji. Człowiek nie działa dlatego, że w konkretnej chwili ma taki a nie inny skład chemiczny krwi lub stan nerwowy, a nawet przeciwnie "nienormalne" stany nerwowe tłumaczą

\footnotetext{
Dz.U. nr 78 poz. 483, dalej: Konstytucja RP.

4 Preambuła Konstytucji RP.
} 
patologię decyzji czy działania. Ostateczną racją wszelkich działań ludzkich jest osoba, która jest jedynym celem, a nie środkiem do celu. Nawet jeśli w jakimś niemoralnym akcie osoba stałaby się środkiem do innego celu, to tym innym celem jest zawsze osoba [Krąpiec, 1993, s. 140]. Najbardziej czytelnie ujął to I. Kant: „Postępuj tak, abyś człowieczeństwa tak w twojej osobie, jak też w osobie każdego innego używał zawsze zarazem jako celu, nigdy tylko jako środka [Kant, 2001, s. 62]. A. Krąpiec podsumuje zaś tę myśl wezwaniem: „człowieczeństwo w naszej osobie musi być dla nas samych święte" [Krąpiec, 1993, s. 140].

Przypomnieć wypada, że w orzecznictwie Trybunału Konstytucyjnego godność jest jedyną wartością, która ma charakter aksjomatyczny (nie musi być dowodzona). Nazywana jest wartościq fundamentalna systemu prawa, która ma powiązania z innymi zasadami naczelnymi ${ }^{5}$. Dlatego Trybunał podkreśla, że zakaz jej naruszania ma charakter bezwzględny ${ }^{6}$. Trybunał Konstytucyjny podkreśla w swoim orzecznictwie, że godność jest „wartością absolutną”, a więc wśród wartości, jakie wyraża Konstytucja RP z 1997 r., nie ma wartości wyższej od niej. Godność nie zależy od okoliczności. M. Granat podkreślił, że godności człowieka przysługuje prymat wśród wartości konstytucyjnych i prymat ten jest bezwzględny [Granat, 2016, s. 14 i nast.].

\section{System pomocy bezdomnym}

Mając na uwadze złożoność problemu, w ustawie z dnia 12 marca 2004 r. o pomocy społecznej przewidziano dwa typy wsparcia dla osób bezdomnych - pomoc pasywną i aktywną. I. Sierpowska [Sierpowska, 2016,

Wyrok TK z 30 października 2006 r., sygn. akt P 10/06, OTK-A 2006, nr 9, poz. 128.

6 Wyroki TK z: 24 lutego 2010 r., sygn. akt K 6/09, OTK-A 2010, nr 2, poz. 15; 30 września 2008 r., sygn. akt K 44/07, OTK-A 2008, nr 7, poz. 126.

T.j. Dz.U. z 2018 r. poz. 650, 700 z późn. zm., dalej: u.p.s. s. 35-37] zauważa, że pomoc pasywna umożliwia zaspokojenie podstawowych potrzeb bytowych w zakresie dostarczenia odzieży, wyżywienia, schronienia, a także skorzystania z opieki medycznej, natomiast celem pomocy aktywnej jest wyjście z bezdomności. Pomoc aktywna wymaga znacznego zaangażowania zainteresowanego, współpracy z instytucją pomocową, a nade wszystko chęci zmiany sytuacji życiowej. W zamian za aktywną postawę państwo oferuje pomoc w znalezieniu pracy, mieszkania, obejmuje osobę bezdomną ubezpieczeniem zdrowotnym, świadczy usługi w postaci poradnictwa, a także proponuje wsparcie finansowe. Wskazana pomoc udzielana jest na podstawie swoistej umowy zawieranej z bezdomnym wyrażającym chęć aktywizacji. Porozumienie to przyjmuje formę kontraktu socjalnego, indywidualnego programu zatrudnienia socjalnego lub specjalnie dedykowanego dla omawianej grupy świadczeniobiorców indywidualnego programu wychodzenia z bezdomności (art. 49 u.p.s.).

Celem tego programu jest udzielenie wsparcia ułatwiającego zmianę stylu życia. Dlatego też koncentruje się on na próbach uporządkowania i ustabilizowania sytuacji życiowej i rodzinnej bezdomnego oraz udzieleniu pomocy w znalezieniu mieszkania i pracy. Ta kompleksowa pomoc ma po części charakter usamodzielniający, po części integracyjny. W ustawie nie wskazano, jakiej konkretnie pomocy udziela się osobie objętej indywidualnym programem wychodzenia z bezdomności (poza opłacaniem składek na ubezpieczenie zdrowotne). Dopuszcza się wszelkie możliwe formy wsparcia, jakimi dysponuje ośrodek pomocy społecznej. Program opracowuje pracownik tego ośrodka wraz z osobą bezdomną, a zatwierdza go kierownik ośrodka. Jeżeli osoba bezdomna przebywa w schronisku, program może przygotować pracownik socjalny tej placówki. Jeżeli indywidualny program wychodzenia z bezdomności wykracza poza finan- 
sowe możliwości placówki, to wymaga on zatwierdzenia przez kierownika ośrodka pomocy społecznej. W programie wskazuje się podmioty odpowiedzialne za realizację jego postanowień. Inicjatywa opracowania programu może wyjść od osoby bezdomnej, może z nią wystąpić również placówka pomocy społecznej. Opracowanie programu powinna poprzedzać analiza sytuacji beneficjenta, przyczyn jego bezdomności oraz motywów jego postępowania. Każdy program wychodzenia z bezdomności dostosowany jest do indywidualnego przypadku, a w jego opracowaniu powinien brać udział sam zainteresowany, bezdomny powinien wyartykułować swoje oczekiwania i określić zobowiązania, które jest w stanie wykonać (np. niespożywanie alkoholu, aktywne poszukiwanie pracy). Warunkiem sukcesu przedsięwzięcia jest aktywne zaangażowanie samego zainteresowanego w opracowanie i realizację programu. Osoby objęte indywidualnym programem wychodzenia z bezdomności podlegają obowiązkowi ubezpieczenia zdrowotnego, dzięki czemu zyskują pełny dostęp do opieki medycznej. Obowiązek ubezpieczenia wymienionych osób powstaje od dnia rozpoczęcia realizacji indywidualnego programu wychodzenia z bezdomności, a wygasa z dniem zakończenia lub zaprzestania realizacji programu. Zgłoszeniem osoby bezdomnej do ubezpieczenia zdrowotnego oraz opłacaniem składek zajmuje się ośrodek pomocy społecznej realizujący program. Podstawą wymiaru składek na ubezpieczenie zdrowotne dla osób objętych indywidualnym programem wychodzenia z bezdomności jest maksymalna kwota zasiłku stałego z pomocy społecznej.

I. Sierpowska podkreśla, że opracowywanie indywidualnych programów socjalnych ma wiele zalet. Pozwala na skonkretyzowanie oczekiwań, wyznaczenie celów i sposobów przełamania procesu ekskluzji społecznej. Zachęca świadczeniobiorców do aktywności i współdziałania z instytucjami udzielającymi wsparcia. Ponadto programy ułatwiają kontrolę nad wykorzystaniem świadczeń przez ich beneficjentów, są nie tylko warunkiem przyznania świadczeń, ale również motywacją do poprawy sytuacji życiowej osób objętych pomocą socjalną. Zasadność i sens pomocy aktywnej nie budzą dziś wątpliwości, a nakłady na nie wymagają szerszego uzasadnienia. Trudno przecenić ich skuteczność, oprócz pomocy udzielonej konkretnemu człowiekowi, aktywne wsparcie przywraca do społeczeństwa osoby żyjące na jego marginesie, włącza je w pomnażanie wspólnego dobra, oddziałuje edukacyjnie, kształtując życiową odpowiedzialność i przeciwdziałając życiu na koszt społeczeństwa [ibidem, s. 39].

Kreowanie nowych form pomocy osobom bezdomnym zawsze rodzić będzie pytanie o ich pożądane cechy. R. Mędrzycki stwierdza, że o ile warta odrębnego przedyskutowania jest możliwość transponowania wprost na grunt polski obcych rozwiązań, o tyle można zakładać, że istnieją transnarodowo pożądane cechy nowych form pomocy osobom bezdomnym. Zaliczyć do nich należy: 1) zróżnicowanie, u podłoża którego leży odpowiednie rozpoznanie problemu bezdomności, 2) trwałość stosowania formy, oraz 3) właściwe ukierunkowanie, któremu towarzyszyć musi jednak kompleksowość rozwiązań. Kreowanie innowacji w przypadku przeciwdziałania bezdomności wymaga interdyscyplinarności, zwłaszcza, że pożądanym zjawiskiem jest sytuacja aplikacji nowych form oparta na gruntownej wiedzy o danym zjawisku [Mędrzycki, 2016, s. 72]. Warto w tym kontekście przytoczyć wnioski R. Mędrzyckiego dotyczące przeciwdziałania bezdomności jako zadania publicznego:

1. „samo pojęcie [bezdomności] powinno traktować się możliwie szeroko, aby ująć w nim zapobieganie, interwencję i reintegrację (inkluzję) osób bezdomnych,

2. przeciwdziałanie bezdomności w każdym z tych aspektów należy traktować jako potrzebę zarówno indywidualną, jak 
i społeczną uzasadnioną wartościami systemu prawnego,

\section{dlatego też}

3. istnieje potrzeba zaangażowania wszystkich władz publicznych w przeciwdziałanie bezdomności i brak możliwości „swoistej ucieczki" na rzecz realizacji zadań w tym zakresie wyłącznie przez podmioty niepubliczne (granice uspołecznienia),

4. należy odbyć merytoryczną debatę nad potrzebą utworzenia działu administracji rządowej „przeciwdziałanie bezdomności", jak i samą ustawą dotyczącą osób bezdomnych,

5. należy dążyć do silnej realizacji zasady indywidualizacji świadczeń w stosunku do osób bezdomnych, jak i kompleksowości tych świadczeń,

6. nowoczesna legislacja dotycząca przeciwdziałania bezdomności musi obejmować uregulowanie pomocy "na styku" bezdomności, w tym z uwzględnieniem fazowości bezdomności,

7. oznacza to również konieczność legislacyjnej zmiany w kierunku upowszechnienia programu typu "Najpierw Mieszkanie" dla osób długotrwałe bezdomnych z innymi obciążeniami chorobowymi,

8. należy rozpocząć dyskusję nad ujmowaniem bezdomności jako stanu ogniskującego wiele rodzajów ubóstwa" [Mędrzycki, 2017, s. 306-307].

Może zbyt daleko idącym jest postulat wyodrębnienia działu administracji rządowej:

\section{Literatura}

Bartnik Cz. (1995). Personalizm. Lublin: Oficyna Wydawnicza Czas.

Boć J. (red.) (2004). Prawo administracyjne, wyd. 10 popr. Wrocław: Kolonia Limited.

Chrisidu-Budnik A., Korczak J., Pakuła A., Supernat J. (2005). Nauka organizacji i zarządzania. Wrocław: Kolonia Limited.

Fundowicz S. (2003). Człowiek i administracja publiczna, w: S. Fundowicz, F. Rymarz, A. Gomułowicz (red.), Prawość i godność. Księga pamiątkowa w 70. Rocznice „przeciwdziałanie bezdomności” (taki postulat mógłby dotyczyć szerszej perspektywy wykluczenia społecznego, którego jednym z najczęściej występujących zjawiskowych postaci jest bezdomność), ale bez wątpienia na przeciwdziałanie bezdomności należy patrzeć z punktu widzenia osoby bezdomnej w jej integralności i kompleksowo rozwiązywać jej problemy, uwzględniając konstytucyjną zasadę solidarności społecznej.

\section{Podsumowanie}

Biorąc pod uwagę personalistyczną koncepcję prawa administracyjnego należy patrzeć na bezdomność przez pryzmat osoby bezdomnej. Osoba bezdomna staje się wyzwaniem dla administracji publicznej, której fundamentalnym celem jest zaspokojenie potrzeb bezdomnego. Uwzględniając rozróżnienie pasywnych i aktywnych form wsparcia, a także konieczność poszukiwania innowacyjnych rozwiązań w zakresie przeciwdziałania bezdomności, wydaje się, że sekwencja działania powinna tutaj następująca: sanacja - socjalizacja - integracja. Nie oznacza to jednak prostego następstwa czasowego. Integralność bytu ludzkiego (osoby) wskazuje, że uzdrawianie wpływa na uspołecznienie i odnajdywanie się w społeczności, ale jednocześnie uspołecznienie i odnajdywanie swojego miejsca w społeczności jest uzdrawiające.

urodzin Profesora Wojciecha Łączkowskiego (s. 97-108). Lublin: Wydawnictwo Katolickiego Uniwersytetu Lubelskiego.

Gacka B. (1996). Personalizm amerykański. Lublin: Redakcja Wydawnictw Katolickiego Uniwersytetu Lubelskiego.

Głombik Cz. (2002). „Osoba i kultura w filozoficznej wizji Jacques'a Maritaina", w: Z. Kuderowicz (red.), Filozofia XX wieku, t. 1 (s. 238-266). Warszawa: Wiedza Powszechna.

Granat W. (1961). Osoba ludzka. Próba definicji. Sandomierz: Wydawnictwo Diecezjalne. 
Granat W. (1976). U podstaw humanizmu chrześcijańskiego. Poznań: Księgarnia św. Wojciecha.

Granat W. (2016). "Godność człowieka a problem bezdomności", w: I. Lipowicz (red.), Bezdomność problemy prawne, innowacyjne rozwiq̨zania (s. 14-28). Warszawa: Fundacja Didactics.

Kant I. (2001). Uzasadnienie metafizyki moralności, tłum. M. Wartenberg. Kęty: Antyk.

Koźmiński A., Piotrowski W. (red.) (1997). Zarzadzanie. Teoria i praktyka, wyd. 3 popr. i rozsz. Warszawa: PWN.

Krąpiec A. (1991). Ja - człowiek. Lublin: Redakcja Wydawnictw Katolickiego Uniwersytetu Lubelskiego.

Krąpiec A. (1993). Człowiek i prawo naturalne. Lublin: Redakcja Wydawnictw Katolickiego Uniwersytetu Lubelskiego.

Krąpiec A. (1996). Suwerenność - czyja? Lublin: Redakcja Wydawnictw Katolickiego Uniwersytetu Lubelskiego.

Maritain J. (1935). O nowa cywilizację chrześcijańską. Lublin: Towarzystwo Wiedzy Chrześcijańskiej.

Maritain J. (1960, 1981). Humanizm integralny. Zagadnienia doczesne i duchowe nowego świata chrześcijańskiego, tłum. J. Budzisz. Londyn: Veritas, Warszawa: Krąg.

Maritain J. (1981). Humanizm integralny. Warszawa: Krąg.

\section{Akty prawne i orzecznictwo}

Konstytucja RP z dnia 2 kwietnia 1997 r., Dz.U. nr 78 poz. 483 z późn. zm.

Ustawa z dnia 12 marca 2004 r. o pomocy społecznej, t.j. Dz.U. z 2018 r. poz. 650, 700 z późn. zm.

Wyrok TK z 30 października 2006 r., sygn. akt P 10/06,

OTK-A 2006, nr 9, poz. 128.
Maritain J. (1988). Osoba ludzka i społeczeństwo, w: J. Maritain, Pisma filozoficzne, tłum. J. Fenrychowa. Kraków: Znak.

Mędrzycki R. (2016). "Nowe formy działania administracji publicznej i partnerów społecznych w zakresie przeciwdziałania bezdomności", w: I. Lipowicz (red.), Bezdomność - problemy prawne, innowacyjne rozwiqzania (s. 62-74). Warszawa: Fundacja Didactics.

Mędrzycki R. (2017). Zadania administracji publicznej w zakresie przeciwdziałania bezdomności. Studium administracyjnoprawne. Warszawa: Wydawnictwo Uniwersytetu Kardynała Stefana Wyszyńskiego.

Mounier E. (1964). „Personalizm”, w: E. Mournier, Wprowadzenie do egzystencjalizmów. Warszawa.

Płużański T. (2002). „Emmanuel Mounier - twórca personalizmu", w: Z. Kuderowicz (red.), Filozofia XX wieku, t. 1 (s. 267-279). Warszawa: Wiedza Powszechna.

Sierpowska I. (2016). „Sytuacja prawna osoby bezdomnej - aktywne czy pasywne formy wsparcia?", w: I. Lipowicz (red.), Bezdomność - problemy prawne, innowacyjne rozwiq̨zania (s. 29-51). Warszawa: Fundacja Didactics.

Wojtyła K. (1994). Osoba i czyn i inne studia antropologiczne. Lublin: Towarzystwo Naukowe Katolickiego Uniwersytetu Lubelskiego.

Zdyb M. (1998). Publiczne prawo gospodarcze. Kraków: Zakamycze.

Wyrok TK z 30 września 2008 r., sygn. akt K 44/07, OTK-A 2008, nr 7, poz. 126.

Wyrok TK z 24 lutego 2010 r., sygn. akt K 6/09, OTK-A 2010, nr 2, poz. 15.

\section{The personalistic concept of public administration and homelessness}

Summary: This article deals with the issues of the personalistic concept of public administration in the context of homelessness. The concept of public administration was discussed, as well as the philosophical foundations of personalism, to get to the concept of a public task. It became necessary to analyse the dignity of the human person as well as the system of help for the homeless.

Bearing in mind the personalistic concept of administrative law, the need to look at homelessness through the prism of a homeless person was stressed.

Keywords: personalistic concept of public administration, philosophical foundations of personalism, dignity of human person, help system for homeless people. 


\section{Prawa autorskie i licencja / Copyright and License}

Artykuł opublikowano na licencji Creative Commons

Uznanie autorstwa - Użycie niekomercyjne - Bez utworów zależnych 3.0 Polska

http://creativecommons.org/licenses/by-nc-nd/3.0/pl/

This article is published under the terms of the Creative Commons Attribution - NonCommercial - NoDerivs (CC BY-NGND 3.0) License http://creativecommons.org/licenses/by-nc-nd/3.0/ 